\title{
Eruption Sequestrum - Case Report and Histopathological Findings
}

\author{
Alexandra Mussolino de QUEIROZ ${ }^{1}$ \\ Cristiane Tomaz ROCHA ${ }^{2}$ \\ Lea Assed Bezerra da SILVA ${ }^{1}$ \\ Luiz Guilherme BRENTEGANI ${ }^{3}$ \\ Raquel Assed Bezerra da SILVA ${ }^{1}$ \\ Andiara DE ROSSI ${ }^{1}$ \\ Paulo NELSON-FILHO ${ }^{1}$ \\ ${ }^{1}$ Department of Pediatric Clinic, Ribeirão Preto Dental School, \\ USP - University of São Paulo, Ribeirão Preto, SP, Brazil \\ ${ }^{2}$ Department of Pediatric Clinics, Dental School, UFCE - Federal University of Ceará, Sobral, CE, Brazil \\ ${ }^{3}$ Department of Stomatology, Ribeirão Preto Dental School, \\ USP - University of São Paulo, Ribeirão Preto, SP, Brazil
}

Eruption sequestrum is an uncommon disturbance in eruption and consists of small fragments of calcified tissue overlying the crowns of erupting permanent molar teeth, especially at the time of eruption of the mandibular first molars. This paper reports a case of unilateral eruption sequestrum in a 7-year-old Brazilian boy and describes its histopathological findings. A white small fragment, 0.5 $\mathrm{cm}$ in diameter, with hard consistency, irregular shape and located on the occlusal surface of the erupting mandibular left first molar was excised. Microscopic examination revealed large trabeculae with empty lacunae and a minimal amount of existing spongy bone consisting of acute inflammatory cells (neutrophils). Signs of necrosis were found on the periphery. The histological analysis was consistent with non-vital bone and the diagnosis of eruption sequestrum was established. Clinical and radiographic follow-up visits scheduled at short intervals and then every 6 months revealed normal postoperative conditions.

Key Words: eruption sequestrum, molar, tooth eruption.

\section{INTRODUCTION}

Eruption sequestrum (ES) is an uncommon condition first reported as an osseous fragment overlying the crown of an erupting permanent molar prior to or immediately after the emergence of the cuspal tips through the oral mucosa (1). ES consists of a small irregular bone spicule, but it can also correspond to the occlusal anatomy of teeth (2). The position of this spicule overlies directly the central occlusal fossa, but within the soft tissue (3). ES may also be retained by tissue covering the distal marginal ridge of an erupting tooth (2).

ES is usually observed at the time of eruption of the mandibular first molars, but it has been noted occurring with maxillary first molars and mandibular second molars $(1,2)$. This major occurrence in mandibular first molars can be due to these teeth with an ectopic path of eruption, with the mesial cusps at some stage lying mesial to the distal root of the second primary molar (3). Thus, a small osseous fragment can occasionally separate from the contiguous bone and emerge through the alveolar bone. In most cases, the small bone fragments are absorbed completely prior to eruption of the molar. However, when the fragments are large or the eruption speed is slow, small bone fragments on the occlusal surface remain unresorbed and exposed to the mucosa prior to molar eruption, which forms ES (1). This can occur due to reduction of osteoclast activity and of bone resorption mediated by dental follicle during tooth eruption caused by apoptosis of reduced enamel epithelium (4).

ES is a mass coronally of the erupting tooth with broader borders (3). If seen radiographically before tooth 
eruption, its intraoral appearance may be predicted(1)

Although ES has been reported as a fragment consisting of compact, non-viable bone $(1,2,5)$, Watkins (3) described a case composed of dentin and covered in areas by fragments of bacteria-infected cementum. Thus further investigations should be performed to elucidate its microscopic aspects. The aim of this paper is to report a case of unilateral ES in a 7-year-old Brazilian boy and to describe its histopathological findings.

\section{CASE REPORT}

A 7-old boy was referred to the Pediatric Dentistry Clinic of Ribeirão Preto Dental School, University of São Paulo, Brazil for routine dental treatment. No significant medical condition was reported. There was neither history of oral-facial trauma nor abnormalities upon extraoral examination. Informed written consent was obtained from the patient's mother and this report was approved by the institutional Ethics Committee (Protocol \#2010.1.532.58.6).

Figures 1 to 3 illustrate the clinical and histopathological features of the case.

Intraoral examination revealed a small white fragment, approximately $0.5 \mathrm{~cm}$ in diameter, with hard consistency and irregular shape, located on the occlusal surface of the erupting mandibular right first molar (Fig. 1). There was neither history of pain nor evidence of dental caries or abnormality in other soft tissues. Periapical radiograph did not show adequately this fragment. The treatment plan included surgical removal of this fragment. A biopsy of the area was excised under local anesthesia. The extracted fragment

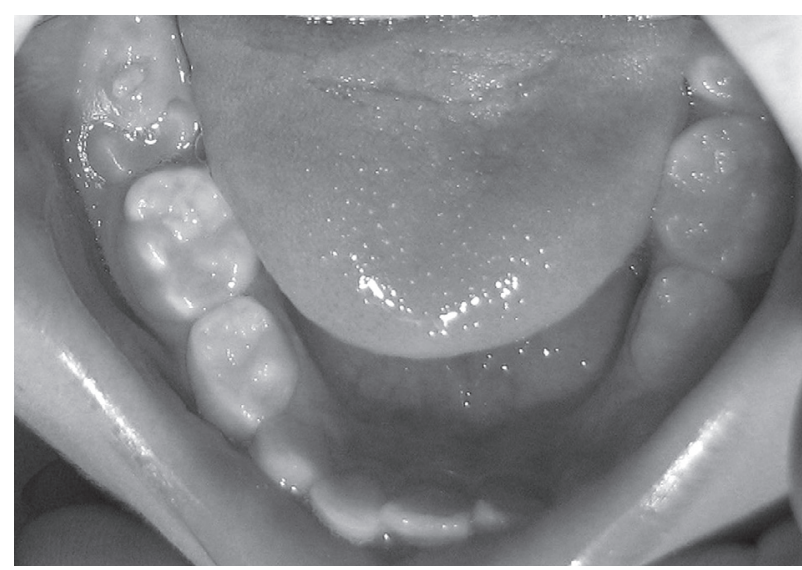

Figure 1. Clinical aspect with tissue overlying occlusal surface of the mandibular right first molar.
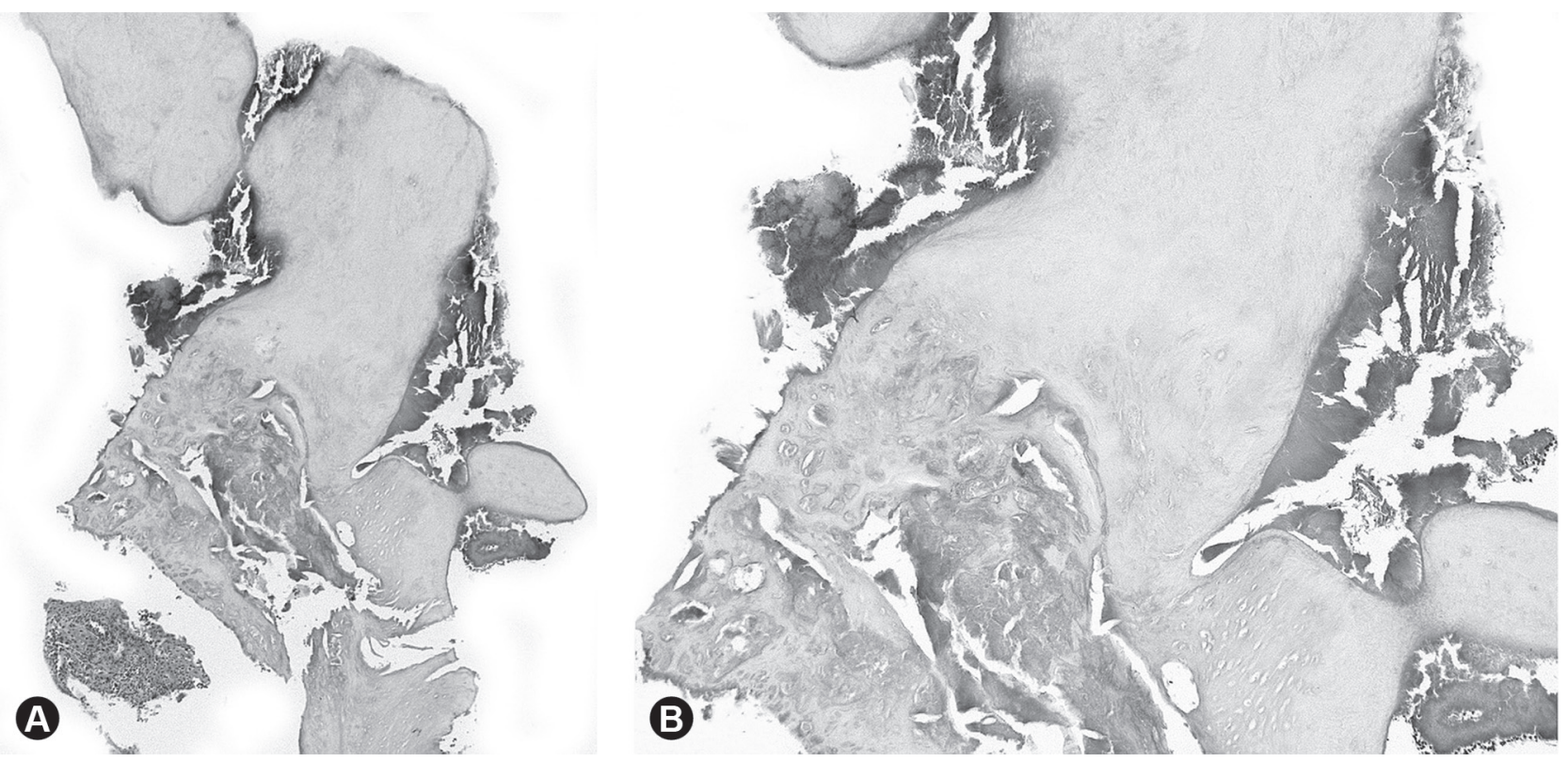

Figure 2. Composite figures of photomicrographs. A: Histopathological aspect of eruption sequestrum characterized by non-vital compact bone. Minimal amount of spongy osseous tissue is contained an apparent inflammatory cell infiltrate. B: In higher magnification, large bone trabeculae with empty lacunae, evidenced by a lack of osteocytes and signs of necrosis on the periphery were also observed. 

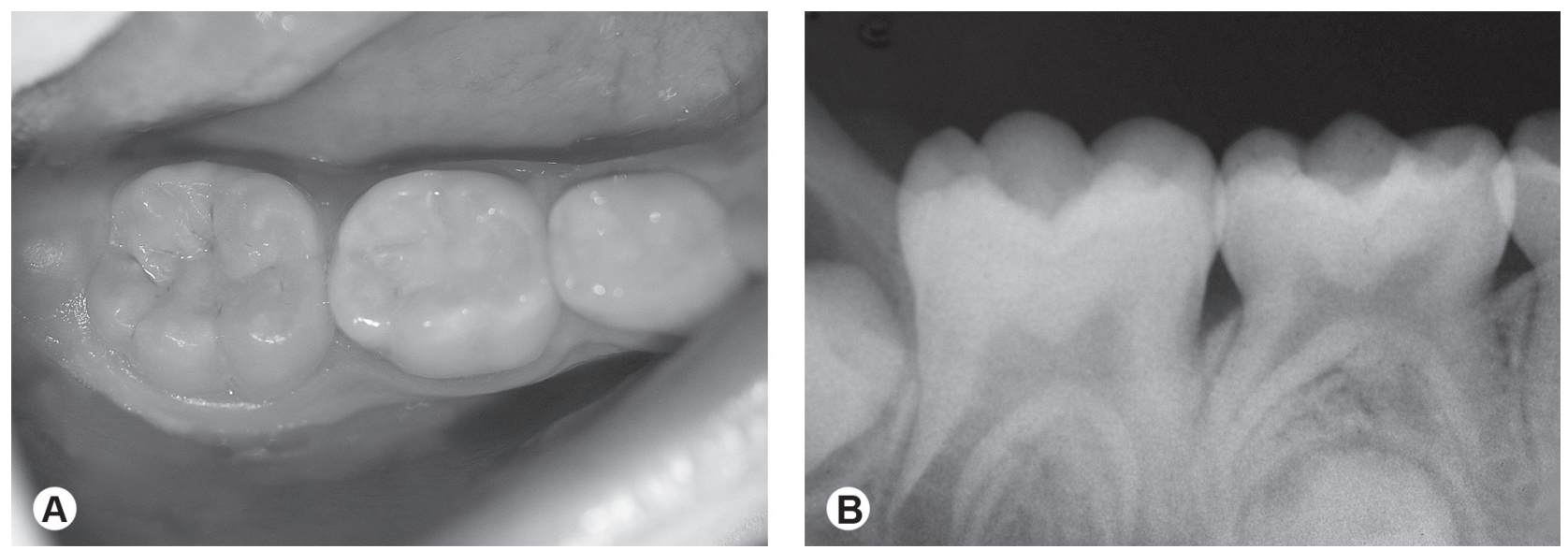

Figure 3. A: Clinical aspect after 6 months showing the mandibular first molar erupted. B: Periapical radiograph showing normal eruption process.

was preserved in formalin for $72 \mathrm{~h}$ and submitted to histological processing for microscopic analysis.

The biopsy tissue was composed of a $0.4 \mathrm{x}$ $0.3 \times 0.3 \mathrm{~cm}$ bone tissue. The microscopic analysis showed non-viable bone tissue of large trabeculae with empty lacunae, evidenced by lack of osteocytes in the lacunae. A minimal amount of existing spongy bone consisted of acute inflammatory cells infiltrate (neutrophils). Signs of necrosis were observed on the periphery. However, no signs of viable bone were evident throughout the specimen. The histological diagnosis was ES (Fig. 2).

At the 1-week postoperative appointment, the patient was evaluated clinically, although no significant signs and symptoms were revealed. After completion of the treatment, follow-up visits were scheduled every 6 months for monitoring dental plaque control as well as for clinical and radiographic assessment (Fig. 3), revealing normal postoperative conditions.

\section{DISCUSSION}

ES is an uncommon clinical finding. It is usually associated with the permanent mandibular first molar $(1,3,5-7)$, as described in the patient of this case.

Although previously thought to have little clinical significance (1), ES may retain biofilm accumulation and lead to pericoronitis, localized swelling, discomfort during mastication, and demineralization or dental caries if it remains for a prolonged time (2). In addition, Maki et al. (9) observed chronic inflammatory alterations in the gingiva in contact with bone and Ho (8) reported a fibromatosis with embedded bone fragment. As its early recognition is important for preventing a future inadequate surgical intervention, the fragment was removed surgically in this patient, as in other cases (2).

In an unusual case of ES, the specimen consisted of a small irregular calcified mass, composed of dentin and covered in areas by fragments of bacteria-infected cementum (3). In the same case, histopathological examination showed non-vital bone, as reported elsewhere $(1,2,5)$. Spongy osseous tissue with an inflammatory cell infiltrate and empty lacuna-like spaces were also identified, in accordance to similar preliminary findings (7). Although ES is rare, it is important to describe its clinical and histological findings for helping clinicians diagnose this condition and updating microscopic descriptions.

\section{RESUMO}

Sequestro de erupção é um distúrbio raro da erupção e consiste de pequenos fragmentos de tecido calcificado que envolvem as coroas dos dentes molares permanentes em erupção, principalmente no momento da erupção dos primeiros molares inferiores. O objetivo deste trabalho é relatar um caso unilateral de sequestro de erupção em um menino brasileiro de 7 anos de idade e descrever seus achados histopatológicos. Um fragmento branco e pequeno, de $0,5 \mathrm{~cm}$ de diâmetro, com consistência dura, de forma irregular e localizado na superfície oclusal do primeiro molar inferior esquerdo em erupção foi excisado. $\mathrm{O}$ exame microscópico revelou trabéculas grandes com lacunas vazias e uma quantidade mínima de osso esponjoso existente consistindo de células inflamatórias agudas (neutrófilos). $\mathrm{Na}$ periferia, sinais de necrose foram evidenciados. A análise histológica foi consistente com osso não-vital e o diagnóstico 
de sequestro de erupção foi estabelecido. Exames clínicos e radiográficos em intervalos curtos e posteriormente semestrais revelaram condições pós-operatórias normais.

\section{REFERENCES}

1. Starkey PE, Shafer WG. Eruption sequestra in children. J Dent Child 1963;30:80-82.

2. Schuler JL, Camm JH, Houston G. Bilateral eruption sequestra: report of case. ASDC J Dent Child 1992;59:70-72.

3. Watkins JJ. An unusual eruption sequestrum. A case report. $\mathrm{Br}$ Dent J 1975;138:395-396.

4. Park SJ, Bae HS, Cho YS, Lim SR, Kang SA, Park JC. Apoptosis of the reduced enamel epithelium and its implications for bone resorption during tooth eruption. J Mol Histol 2012 [Epub ahead of print].

5. Gardner DE, Norwood JR. Eruption sequestra: five case reports. J Dent Child 1978;44:475-476.

6. Kennedy DB. Eruption sequestrae - three case reviews. J Pedodont 1980;4:266-270.

7. Priddy RW, Price C. The so-called eruption sequestrum. Oral Surg Oral Med Oral Pathol 1984;58:321-326.

8. Ho KH. Eruption sequestrum. Ann Acad Med Singapore 1986; 15:454-455.

9. Maki K, Ansai T, Nishida I, Zhang M, Kojima Y, Takehara T, et al.. Eruption sequestrum: $\mathrm{x}$-ray microanalysis and microscopic findings. J Clin Pediatr Dent 2005;29:245-247.

Received May 22, 2012 Accepted November 8, 2012 